\title{
Physiological and Biochemical Basis for Moisture Stress Tolerance in Chickpea under Pot Study
}

\author{
V.R. Awari*, U.S. Dalvi, P.K. Lokhande, V.Y. Pawar, S.N. Mate, \\ R.M. Naik and L.B. Mhase \\ Department of Agricultural Botany, \\ Mahatma Phule Krishi Vidyapeeth, Rahuri 413722 (M.S.), India \\ *Corresponding author
}

\begin{abstract}
A B S T R A C T
Keywords

Chickpea, Osmotic stress, Polyethylene glycol, Photosynthesis, Transpiration, Antioxidant enzymes.

Article Info

Accepted:

12 April 2017

Available Online:

10 May 2017

Water deficit stress is one of the important factors limiting chickpea production in arid and semiarid regions. Water deficit induced b Polyethylene glycol (PEG) affect physiological and biochemical changes in Chickpea. This investigation was undertaken to evaluate morpho-physiological parameters, levels of osmolytes and activities of antioxidative enzymes under PEG 6000 induced osmotic moderate and severe stress in pot. The plants were subjected to two progressive stresses: moderate $(-0.4 \mathrm{MPa})$ and severe stress $(-1.2$ $\mathrm{MPa}$ ). The tolerant genotypes have highest photosynthetic activity with limited rate of transpiration under stress condition as compared to susceptible genotypes. Drought tolerant genotypes had higher relative water content and stomatal conductance. Increase in the proline content during water stress condition suggests that proline is one of the common compatible osmolytes under water stress conditions. The mean activities of antioxidative enzymes such as SOD, Cat and APX were higher in leaves of tolerant genotypes than susceptible types. The present data suggest a relation between proline content and water stress and a well developed antioxidant defense mechanism activated during water stress.
\end{abstract}

\section{Introduction}

Chickpea (Cicer arietinum L.), one of the important legume crops found in the semiarid areas. Chickpea is the third most important grain legume crop in the world and first in the Mediterranean basin and South Asia that frequently experiences water stress during pod set and seed filling stage (terminal drought) in India and the Mediterranean basin, leading to substantial yield loss.

Plants show a lot of morpho-physiological and metabolic changes in response to drought stress. Consequently, these changes lead them to adapting to drought stress conditions. As Sanchez-Mora et al., (2008) mentioned response mechanisms to drought stress are very complicated because in addition to morphological and physiological and metabolic changes, interactions of these factors are also important in resistance to drought stress. Water stress invariably decreases several vital processes of the plant and at the same time, modifies a number of morphological and physiological characters in a manner so that a plant can thrive well under drought. 
Identifying drought tolerant mechanism is essential for measuring stress resistance in large breeding population. For drought stress, polyethylene glycol (PEG) compound has been used to stimulate osmotic stress effect for plants maintain uniform water potential throughout the experimental period. Using this methodology, selection from a large number of breeding lines can be shortly and economically. Water stress $(0,-0.2,-0.4,-0.6$ and $-0.8 \mathrm{MPa}$ ) induced by PEG 6000 affected the germination and seedling development parameters in chickpea genotypes. Seedling growth decreased with decreasing the osmotic potential (Yucel et al., 2010).

The accumulation of osmolytes may ensure the maintenance of the structural integrity of membranes. There are some evidences that plants are more tolerant to water deficit when water is withheld under condition that favour osmotic adjustment. Osmotic adjustment is part of drought avoidance mechanism. Proline is one of the osmolytes, which increases faster than other amino acids in plants under water deficit stress and help the plant to maintain cell turgour. The increase in proline is usually considered as a plant response to drought stress. Higher proline content in tolerant genotypes as compared to susceptible genotypes helps them to improve their cellular osmotic adjustment and also the stabilization of enzymes proteins under drought stress (Kumar et al., 2006).

Drought is the most severe abiotic stress factor limiting plant growth and crop production. When plants are subjected to various abiotic stresses, some reactive oxygen species (ROS) such as superoxide $\left(\mathrm{O}_{2}^{-}\right)$, hydrogen peroxide $\left(\mathrm{H}_{2} \mathrm{O}_{2}\right)$, hydroxyl radicals $(\cdot \mathrm{OH})$ and singlet oxygen $\left({ }^{1} \mathrm{O}_{2}\right)$ are produced.SOD is a major scavenger of $\mathrm{O}_{2}{ }^{-}$ and its enzyme action results in the formation of $\mathrm{H}_{2} \mathrm{O}_{2}$ and $\mathrm{O}_{2}$. Catalase is localized in the mitochondria, peroxisomes and cytoplasm of higher plants (Bray et al., 2000). It is instrumental in the decomposition of $\mathrm{H}_{2} \mathrm{O}_{2}$, which is produced outside the chloroplasts by the $\mathrm{H}_{2} \mathrm{O}_{2}$ generating oxidases present in the peroxisomes.

An alternative defensive system called antioxidative is also activated to protect cells against oxidative stress and support plants against oxidative hurt. The endogenous supportive mechanisms consist of some enzymes like superoxide dismutase (SOD), catalase (CAT), ascorbate peroxidase (APX) as well as, peroxidase (POX) that can effectively scavenge the toxic oxygen species.

Considering all these aspects, the present study was undertaken to study the variation in morpho-physiological, biochemical parameter among various chickpea genotypes under PEG 6000 induced osmotic stress in pot.

\section{Materials and Methods}

The ten genotypes (5 susceptible and 5 tolerant) were grown in pots during rabi 2012-13. After 35 days of seedling growth (before anthesis), plants were divided into three groups control, moderate stress (-0.4 $\mathrm{MPa})$ and severe stress $(-1.2 \mathrm{MPa})$. The moisture stress was induced by irrigating the pot with PEG-6000 solution. The osmotic potential of the solution of treatment was decreased gradually at the rate $-0.1 \mathrm{MPa} /$ alternate two days and -0.3 MPA/alternate two days until the stress level reach $-0.4 \mathrm{MPa}$ (moderate stress) and $-1.2 \mathrm{MPa}$ (severe stress).

The comparative studies were performed in control and treatment group of same age plants. Healthy leaves free of any diseases from control group and stress induced leaves were used for various physiological and biochemical assays. The concentration of PEG 6000 (g/l of water) for each water stress was determined by using the equation of Michel and Kaufman (1973). 


\section{Physiological parameters: Observations recorded by IRGA}

The net photosynthetic rate $\left(\mu \mathrm{mol} \mathrm{CO} \mathrm{CO}_{2} \mathrm{~m}^{-2} \mathrm{~s}\right.$ $\left.{ }^{1}\right)$, transpiration rate $\left(\mathrm{mmol} \mathrm{H}_{2} \mathrm{O} \mathrm{m}^{-2} \mathrm{~s}^{-1}\right)$ and stomatal conductance $\left(\mathrm{mol} \mathrm{H}_{2} \mathrm{O} \mathrm{m}^{-2} \mathrm{~s}^{-1}\right)$ were measured using Infra-Red Gas Analyzer (IRGA; Model Portable Photosynthesis System LI 6400, LI-COR® Inc, Lincoln, Nebraska, USA). The transpiration rate and stomatal conductance were measured continuously monitoring $\mathrm{H}_{2} \mathrm{O}$ of the air entering and leaving in the IRGA headspace chamber and the measurements were made at mid day, between 11:30 and 12:00 eastern day time (1400-1800 mmolm $\mathrm{m}^{-2}$ PPFD), on top fully expanded leaf. The flow-rate of air in the sample line was adjusted to $500 \mu \mathrm{mol} \mathrm{s}$ 1

\section{SPAD chlorophyll meter}

Chlorophyll concentration was assessed using chlorophyll meter (SPAD-502 plus, Minolta). Measurements were taken at three points (upper, middle and lower parts). Average of these three readings was considered as SPAD reading of the leaf. SPAD reading was carried out at $50 \%$ flowering and grain filling stage. The mean SCMR reading was taken out in the end and presented as average SPAD value.

\section{Relative leaf water content (RLWC)}

Relative leaf water content (RLWC) was measured by the method described by Henderson and Davies-Jr. (1990).

\section{Protocol}

The leaves from the top of the main stem was detached from 5 randomly selected plants and kept in sealable plastic bag in an ice box. The leaf samples were brought to a laboratory where fresh weight was recorded immediately. The leaf samples were then immediately hydrated to full turgidity for 2 hours by floating on de-ionized water in a close petri-dish under room temperature. After 2 hours the samples were taken out of water and were well dried with a filter paper.

They were immediately weighted to obtain fully turgid weight (TW). Samples were then dried at $80{ }^{\circ} \mathrm{C}$ for $36 \mathrm{~h}$ and dry weight (DW) was determined. The RLWC was calculated by using the following formula.

RLWC, $\%=[(\mathrm{FW}-\mathrm{DW}) /(\mathrm{TW}-\mathrm{DW})] \mathrm{X} 100$

where, $\mathrm{FW}=$ fresh weight, $\mathrm{TW}=$ turgid weight, DW= dry weight

\section{Biochemical parameters}

\section{Proline}

Proline content in leaf tissues of both control and drought stress chickpea at 50\% flowering was determined using the acid ninhydrin reagent as per the method described by Bates et al., (1973). The proline content was expressed as $\mu$ moles per gram fresh weight.

\section{Glycine betaine}

Glycine betaine content in leaves of both the unstressed and stressed seedlings was determined by using the Dragendorff reagent as per the method described by Stumpf (1984). The glycine betaine content was expressed as $\mu$ moles $\mathrm{g}^{-1} \mathrm{FW}$

\section{Enzymes extraction}

Antioxidative enzymes such as superoxide dismutase (SOD), catalase (CAT), ascorbate peroxidase (APX) and guaiacol peroxidase (POX) were extracted from leaf tissue by using the method of Costa et al., (2002).

\section{Superoxide dismutase}

Superoxide dismutase activity was determined by measuring its ability to inhibit 
the photochemical reduction of nitroblue tetrazolium using the method described by Dhindsa et al., (1981).

\section{Catalase}

Catalase activity was measured immediately in fresh extract and the assay employed was the one described by Aebi (1984). The hydrogen peroxide dependent oxidation was estimated by the decrease in absorbance at $240 \mathrm{~nm}$.

\section{Ascorbate peroxidase}

Ascorbate peroxidase activity was measured immediately in fresh extract which was assayed as per the method described by Nakano and Asada (1981).

\section{Results and Discussion}

Chickpea responses were studied to progressive induced different levels of osmotic stress in the pot by using PEG 6000. Several methods which range from withdrawal of water to plants to the use of chemicals such as polyethylene glycol, mannitol etc. are being employed to create water stress in plants. It has been reasonably well established that polyethylene glycol induced water stress mimics that caused by withdrawal of water from plants.

\section{Photosynthetic rate}

In the present study, the PEG induced water stress decreased the net photosynthesis as osmotic stress increased. The significant decrease in the rate of photosynthesis was observed in both progressive mild and severe stress. A decrease of 55.4 and 29 per cent was noted in susceptible and tolerant genotypes under moderate stress, while sharp decrease of 88 and 75 per cent was observed in susceptible and tolerant genotypes, respectively, as compared to control under severe stress.

Stomatal closure can serve as a rapid and effective drought avoidance response. However, prolonged stomatal closure is not suitable as stomatal $\mathrm{CO}_{2}$ uptake is also reduced and will ultimately limit photosynthesis assimilation and growth. The genotype ICC 4958 recorded the highest mean rate of photosynthesis (10.73 and $3.59 \mu$ mol m $\mathrm{m}^{-1} \mathrm{~s}^{-1}$ ) under moderate and severe stress, respectively. Decreased $\mathrm{CO}_{2}$ diffusion from the atmosphere to the site of carboxilation is generally considered the main cause of decreased photosynthesis under mild to moderate water limitations (Chaves et al., 2003; 2009 and Grassi and Magnani, 2005). Similar results were reported by Kataria and Singh (2013).

\section{Transpiration rate}

The mean rate of transpiration was higher in unstressed control condition than in moderate and severe stress. The reduction in rate of transpiration was with 11.97 per cent in susceptible genotypes and in tolerant genotypes with 16.60 per cent over unstressed control under moderate stress.

The higher per cent decrease in the rate of transpiration of 84.3 was observed in tolerant genotypes than the susceptible genotypes with 77.1 per cent reduction under severe stress. Limited rate of transpiration was observed by the tolerant genotype ICC 4958 (1.39 and $\left.0.43 \mathrm{~m} \mathrm{~mol} \mathrm{~m}^{-2} \mathrm{~s}^{-1}\right)$ followed by Vijay (1.45 and $\left.0.53 \mathrm{~m} \mathrm{~mol} \mathrm{~m}^{-2} \mathrm{~s}^{-1}\right)$ under moderate and severe stress, respectively.

\section{Stomatal conductance}

The mean stomatal conductance of the leaves of chickpea genotypes was significantly decreased under stress condition. The tolerant 
genotypes Vijay showed minimum reduction in stomatal conductance which was decreased from 0.22 to 0.15 and 0.22 to $0.11 \mathrm{~mol} \mathrm{~m}^{-2} \mathrm{~s}^{-1}$ under moderate and severe stress, respectively.

In the present study, significant decrease in net photosynthesis, stomatal conductance and transpiration were associated with the significant decrease in plant growth. The tolerant genotypes ICC 4958, Digvijay and Vijay had the higher photosynthetic activity and stomatal conductance under stress. Decrease in plant water status was associated with significant decline in net photosynthetic rates. Decreased relative water content under drought leading to reduced leaf turgour might be responsible for the observed reduction in photosynthesis during the present study. Reduction in stomatal conductance under stress was reported in linseed by Khan et al., (2010) and in chickpea by Hirich et al., (2014).

\section{SCMR values}

The chlorophyll meter (SPAD-502 Minolta, Tokyo, Japan) also known as SPAD (Soil Plant Analysis Development) meter, can quickly and reliably asses the $\mathrm{N}$ status of a crop basal on leaf area. In addition, a SPAD chlorophyll meter reading (SCMR) is an indicator of the photosynthetically active light -transmittance characteristics of the leaf, which is dependent on the amount of chlorophyll per unit leaf area (chlorophyll density).

SCMR value was affected during present investigation which shows that progressive stress along with some other environmental factor may affect photosynthetic ability of the plant system. Overall on the mean basis, it is observed that susceptible genotypes Phule G09103 (38.04) and Phule G-0305-3 (39.05) were more sensitive than the tolerant genotypes Vijay (48.44) and ICC 4958
(48.02). Minimum reduction in RLWC was observed in Vijay from 57.50 to 47.25 and 40.48 per cent (17.9 and 29.7 per cent decrease) over unstressed plant, respectively. A reason for decrease in SCMR value as affected by water stress deficit is that the moisture stress produces reactive oxygen species (ROS) such as $\mathrm{O}_{2}^{-}$and $\mathrm{H}_{2} \mathrm{O}_{2}$, which can lead to lipid peroxidation and consequently, chlorophyll destruction with decreasing chlorophyll content due to changing green colour of the leaf into yellow. Naderikharaji et al., (2008) reported similar decrease in SPAD value under stress in rapeseed.

\section{Relative Water Content (RLWC)}

Limited supply of water lead to dehydration of plants, decrease in RLWC and loss of turgour of leaves, which can results in stomata closes. Maximum decrease in RLWC from 68.32 to 56.87 and 30.58 per cent (16.7 and 55.2 per cent reduction) was observed in susceptible genotype Phule G-09 103 at moderate and severe stress. While minimum decrease in RLWC over control plants was observed in ICC 4958 with 14.2 and 18.18 per cent reduction in both progressive moderate and severe stress, respectively.

The ability of plant to maintain the turgour and related physiological process even under water stress condition has a great practical significance and it is related with drought resistance in terms of osmoregulatory activities. Decrease in RLWC in PEG induced water stress was reported in rice leaves (Zgalli, 2005 and Bayomi et al., 2008).

\section{Proline}

A variety of organic solutes accumulates in osmotically stressed plants in which proline appears to be widely distributed osmolytes under stress condition. 
Table.1 Effect of PEG-6000-induced osmotic stress on rate of photosynthesis $\left(\mu \mathrm{mol} \mathrm{m} \mathrm{s}^{-2}\right)$, Transpiration rate $\left(\mathrm{m} \mathrm{mol} \mathrm{m}^{-2} \mathrm{~s}^{-1}\right)$ and Stomatal conductance $\left(\mathrm{mol} \mathrm{m}^{-2} \mathrm{sec}^{-1}\right)$ at $50 \%$ flowering in susceptible and tolerant chickpea genotypes

\begin{tabular}{|c|c|c|c|c|c|c|c|c|c|c|}
\hline \multirow[b]{2}{*}{$\begin{array}{l}\text { Sr. } \\
\text { No. }\end{array}$} & \multirow[b]{2}{*}{ Genotypes } & \multicolumn{3}{|c|}{ Rate of photosynthesis $\left(\mu \mathrm{mol} \mathrm{m} \mathrm{m}^{-2} \mathrm{~s}^{-1}\right)$} & \multicolumn{3}{|c|}{ 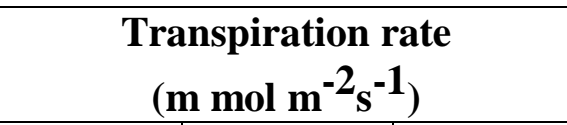 } & \multicolumn{3}{|c|}{$\begin{array}{l}\text { Stomatal conductance } \\
\quad\left(\mathrm{mol} \mathrm{m}^{-2} \mathrm{sec}^{-1}\right)\end{array}$} \\
\hline & & Control & $\begin{array}{l}\text { Moderate } \\
\text { Stress } \\
(-0.4 \mathrm{MPa})\end{array}$ & $\begin{array}{l}\text { Severe Stress } \\
(-1.2 \mathrm{MPa})\end{array}$ & Control & $\begin{array}{l}\text { Moderate } \\
\text { Stress } \\
(- \\
\text { 0.4MPa) }\end{array}$ & $\begin{array}{l}\text { Severe } \\
\text { Stress } \\
(-1.2 \\
\text { MPa })\end{array}$ & Control & $\begin{array}{l}\text { Moderate } \\
\text { Stress } \\
(- \\
\text { 0.4MPa) }\end{array}$ & $\begin{array}{l}\text { Severe } \\
\text { Stress } \\
(-1.2 \\
\text { MPa })\end{array}$ \\
\hline 1 & Phule G-0305-3 & 12.44 & 5.46 & 1.64 & 4.87 & 2.06 & 1.17 & 0.13 & 0.09 & 0.07 \\
\hline 2 & Phule G 0405-44-2 & 11.68 & 5.55 & 1.32 & 4.77 & 1.90 & 1.08 & 0.17 & 0.11 & 0.07 \\
\hline 3 & Phule G 09103 & 11.75 & 4.80 & 1.43 & 4.89 & 2.21 & 1.01 & 0.16 & 0.09 & 0.05 \\
\hline 4 & ICCV 11112 & 13.49 & 6.16 & 1.27 & 3.26 & 1.74 & 0.94 & 0.18 & 0.11 & 0.06 \\
\hline \multirow[t]{2}{*}{5} & ICCV 11117 & 12.20 & 5.45 & 1.54 & 5.84 & 2.36 & 1.20 & 0.18 & 0.10 & 0.05 \\
\hline & Susceptible mean & 12.31 & 5.48 & 1.44 & 4.73 & 2.05 & 1.08 & 0.16 & 0.10 & 0.06 \\
\hline 6 & Phule G 0511-43-2 & 13.24 & 9.37 & 2.95 & 4.08 & 1.54 & 0.68 & 0.15 & 0.09 & 0.08 \\
\hline 7 & Phule G 0752 & 12.08 & 8.18 & 2.66 & 3.65 & 1.29 & 0.59 & 0.18 & 0.12 & 0.09 \\
\hline 8 & ICC 4958 & 14.31 & 10.73 & 3.59 & 3.26 & 1.39 & 0.43 & 0.21 & 0.15 & 0.08 \\
\hline 9 & Vijay & 12.19 & 8.71 & 3.28 & 3.35 & 1.45 & 0.53 & 0.22 & 0.15 & 0.11 \\
\hline \multirow[t]{8}{*}{$\mathbf{1 0}$} & Digvijay & 13.22 & 9.06 & 3.40 & 3.57 & 1.50 & 0.58 & 0.19 & 0.15 & 0.08 \\
\hline & Tolerant mean & 13.01 & 9.21 & 3.17 & 3.58 & 1.43 & 0.56 & 0.19 & 0.13 & 0.09 \\
\hline & Mean & 12.66 & 7.35 & 2.31 & 4.15 & 1.74 & 0.82 & 0.18 & 0.12 & 0.07 \\
\hline & & & $\mathrm{SE}_{ \pm}$ & CD at $5 \%$ & & $\mathrm{SE}_{ \pm}$ & $\begin{array}{ll}\text { CD } & \text { at } \\
\mathbf{5 \%} & \end{array}$ & & $\mathrm{SE}_{ \pm}$ & $\begin{array}{ll}\text { CD } & \text { at } \\
5 \% & \end{array}$ \\
\hline & \multicolumn{2}{|l|}{ Condition } & 0.08 & 0.21 & & 0.025 & 0.070 & & 0.002 & 0.004 \\
\hline & \multicolumn{2}{|l|}{ Genotype } & 0.04 & 0.13 & & 0.015 & 0.043 & & 0.001 & 0.003 \\
\hline & \multicolumn{2}{|c|}{ Condition X Genotype } & 0.24 & 0.67 & & 0.078 & 0.22 & & 0.005 & 0.014 \\
\hline & \multicolumn{2}{|l|}{$\mathrm{CV} \%$} & & 5.54 & & & 6.05 & & & 6.81 \\
\hline
\end{tabular}


Table.2 Effect of PEG-6000-induced osmotic stress on SCMR value and Relative Leaf Water Content (\%)at 50\% flowering in susceptible and tolerant chickpea genotypes

\begin{tabular}{|c|c|c|c|c|c|c|c|}
\hline \multirow[b]{2}{*}{ Sr. No. } & \multirow[b]{2}{*}{ Genotypes } & \multicolumn{3}{|c|}{ SCMR value } & \multicolumn{3}{|c|}{ Relative Leaf Water Content (\%) } \\
\hline & & Control & $\begin{array}{l}\text { Moderate } \\
\text { Stress } \\
(-\mathbf{0 . 4 M P a )}\end{array}$ & $\begin{array}{l}\text { Severe Stress } \\
(-1.2 \mathrm{MPa})\end{array}$ & Control & $\begin{array}{l}\text { Moderate } \\
\text { Stress } \\
(-\mathbf{0 . 4 M P a )}\end{array}$ & $\begin{array}{l}\text { Severe } \\
\text { Stress } \\
(-1.2 \mathrm{MPa})\end{array}$ \\
\hline 1 & Phule G-0305-3 & 51.65 & 36.09 & 29.41 & 64.24 & 53.53 & 36.61 \\
\hline 2 & Phule G 0405-44-2 & 54.61 & 38.81 & 32.99 & 65.61 & 57.07 & 33.85 \\
\hline 3 & Phule G 09103 & 52.05 & 35.17 & 26.90 & 68.32 & 56.87 & 30.58 \\
\hline 4 & ICCV 11112 & 55.41 & 41.84 & 29.14 & 65.56 & 57.41 & 34.59 \\
\hline \multirow[t]{2}{*}{5} & ICCV 11117 & 54.20 & 39.44 & 33.52 & 64.63 & 54.96 & 39.34 \\
\hline & Susceptible mean & 53.58 & 38.27 & 30.39 & 65.67 & 55.97 & 34.99 \\
\hline 6 & Phule G 0511-43-2 & 57.05 & 44.33 & 37.65 & 67.95 & 59.23 & 51.56 \\
\hline 7 & Phule G 0752 & 56.37 & 44.36 & 38.78 & 68.08 & 61.99 & 52.26 \\
\hline 8 & ICC 4958 & 58.56 & 46.64 & 38.87 & 69.11 & 62.05 & 56.58 \\
\hline 9 & Vijay & 57.60 & 47.25 & 40.48 & 70.15 & 64.38 & 51.26 \\
\hline \multirow[t]{8}{*}{10} & Digvijay & 54.26 & 43.72 & 37.45 & 69.24 & 62.52 & 53.35 \\
\hline & Tolerant mean & 56.77 & 45.26 & 38.65 & 68.91 & 62.03 & 53.00 \\
\hline & Mean & 55.18 & 41.76 & 34.52 & 67.29 & 59.00 & 44.00 \\
\hline & & & $\mathrm{SE}_{ \pm}$ & CD at $5 \%$ & & $\mathbf{S E} \pm$ & CD at $5 \%$ \\
\hline & Condition & & 0.36 & 1.01 & & $0.4 \overline{2}$ & 1.18 \\
\hline & Genotype & & 0.21 & 0.62 & & 0.25 & 0.72 \\
\hline & Condition X Genotype & & 1.13 & 3.22 & & 1.32 & 3.73 \\
\hline & $\mathrm{CV} \%$ & & & 4.50 & & & 4.02 \\
\hline
\end{tabular}


Table.3 Effect of PEG-6000 induced osmotic stress on proline and glycine betaine content in the leaves of susceptible and tolerant chickpea genotypes

\begin{tabular}{|c|c|c|c|c|c|c|c|}
\hline \multirow[b]{2}{*}{ Sr. No. } & \multirow[b]{2}{*}{ Genotypes } & \multicolumn{3}{|c|}{ Proline ( $\mu$ moles $\left.\mathbf{g}^{-1} \mathbf{F W}\right)$} & \multicolumn{3}{|c|}{ Glycine betaine ( $\mu$ moles $\mathrm{g}^{-1} \mathrm{FW}$ ) } \\
\hline & & Control & $\begin{array}{l}\text { Moderate } \\
\text { Stress } \\
\text { (-0.4MPa) }\end{array}$ & $\begin{array}{l}\text { Severe Stress } \\
(-1.2 \mathrm{MPa})\end{array}$ & Control & $\begin{array}{l}\text { Moderate } \\
\text { Stress } \\
(-\mathbf{0 . 4 M P a )}\end{array}$ & $\begin{array}{l}\text { Severe } \\
\text { Stress } \\
(-1.2 \mathrm{MPa})\end{array}$ \\
\hline 1 & Phule G-0305-3 & 4.02 & 5.06 & 11.75 & 4.94 & 7.22 & 10.16 \\
\hline 2 & Phule G 0405-44-2 & 5.58 & 7.48 & 14.86 & 4.77 & 6.56 & 9.30 \\
\hline 3 & Phule G 09103 & 5.08 & 6.47 & 12.88 & 4.09 & 6.09 & 7.64 \\
\hline 4 & ICCV 11112 & 5.65 & 6.52 & 15.71 & 5.83 & 8.35 & 10.26 \\
\hline \multirow[t]{2}{*}{5} & ICCV 11117 & 3.53 & 6.02 & 12.10 & 6.14 & 8.30 & 12.43 \\
\hline & Susceptible mean & 4.77 & 6.31 & 13.46 & 5.15 & 7.30 & 9.96 \\
\hline 6 & Phule G 0511-43-2 & 6.04 & 9.94 & 18.10 & 8.52 & 14.30 & 22.00 \\
\hline 7 & Phule G 0752 & 6.02 & 9.77 & 20.44 & 6.39 & 10.39 & 18.09 \\
\hline 8 & ICC 4958 & 5.39 & 9.63 & 21.50 & 7.39 & 12.65 & 25.16 \\
\hline 9 & Vijay & 4.59 & 9.86 & 22.98 & 6.91 & 15.42 & 24.61 \\
\hline \multirow[t]{8}{*}{10} & Digvijay & 5.30 & 9.60 & 21.15 & 7.68 & 14.23 & 22.96 \\
\hline & Tolerant mean & 5.468 & 9.76 & 20.83 & 7.78 & 13.40 & 22.56 \\
\hline & Mean & 5.12 & 8.03 & 17.15 & 6.27 & 10.35 & 16.26 \\
\hline & & & $\mathrm{SE}_{ \pm}$ & CD at $5 \%$ & & $\mathrm{SE}_{ \pm}$ & CD at $5 \%$ \\
\hline & Condition & & 0.037 & 0.101 & & 0.06 & 0.16 \\
\hline & Genotype & & 0.022 & 0.063 & & 0.04 & 0.10 \\
\hline & Condition X Genotype & & 0.11 & 0.33 & & 0.18 & 0.51 \\
\hline & $\mathrm{CV} \%$ & & & 1.99 & & & 2.75 \\
\hline
\end{tabular}


Table.4 Effect of PEG-6000-induced osmotic stress on superoxide dismutase, catalase and ascorbate peroxidas in the leaves of susceptible and tolerant chickpea genotypes

\begin{tabular}{|c|c|c|c|c|c|c|c|c|c|c|}
\hline \multirow{2}{*}{$\begin{array}{l}\text { Sr. } \\
\text { No. }\end{array}$} & \multirow[b]{2}{*}{ Genotypes } & \multicolumn{3}{|c|}{$\begin{array}{l}\text { Superoxide dismutase } \\
\text { (units } \mathrm{mg}^{-1} \text { protein) }\end{array}$} & \multicolumn{3}{|c|}{$\begin{array}{l}\text { Catalase } \\
\left(\mu \text { mole } \mathrm{H}_{2} \mathrm{O}_{2} \text { decomposed }\right. \\
\left.\mathrm{mg}^{-1} \text { protein } \text { min }^{-1}\right)\end{array}$} & \multicolumn{3}{|c|}{$\begin{array}{l}\text { Ascorbate peroxidase } \\
(\eta \text { moles of ascorbate oxidized } \\
\left.\text { mg }^{-1} \text { protein } \text { min }^{-1}\right)\end{array}$} \\
\hline & & Control & $\begin{array}{l}\text { Moderate } \\
\text { Stress } \\
(\mathbf{- 0 . 4 M P a )}\end{array}$ & $\begin{array}{l}\text { Severe } \\
\text { Stress } \\
(-1.2 \mathrm{MPa})\end{array}$ & Control & $\begin{array}{l}\text { Moderate } \\
\text { Stress } \\
(- \\
\text { 0.4MPa) }\end{array}$ & $\begin{array}{l}\text { Severe } \\
\text { Stress } \\
(-1.2 \\
\text { MPa) } \\
\end{array}$ & Control & $\begin{array}{l}\text { Moderate } \\
\text { Stress } \\
(-0.4 M P a)\end{array}$ & $\begin{array}{l}\text { Severe } \\
\text { Stress } \\
(-1.2 \\
\text { MPa) } \\
\end{array}$ \\
\hline 1 & Phule G-0305-3 & 72.24 & 114.10 & 167.97 & 6.32 & 8.89 & 20.71 & 226.78 & 459.32 & 589.03 \\
\hline 2 & Phule G 0405-44-2 & 71.25 & 119.74 & 172.53 & 6.37 & 9.76 & 17.87 & 151.04 & 321.30 & 459.41 \\
\hline 3 & Phule G 09103 & 69.06 & 121.47 & 163.89 & 7.75 & 10.05 & 22.29 & 233.28 & 452.12 & 598.19 \\
\hline 4 & ICCV 11112 & 63.49 & 113.36 & 165.56 & 6.87 & 10.58 & 25.03 & 281.70 & 431.33 & 740.47 \\
\hline \multirow[t]{2}{*}{5} & ICCV 11117 & 70.63 & 117.50 & 174.14 & 7.52 & 11.66 & 24.76 & 198.49 & 304.05 & 577.54 \\
\hline & Susceptible mean & 69.33 & 117.23 & 168.82 & 6.96 & 10.18 & 22.13 & 218.3 & 393.62 & 592.93 \\
\hline 6 & Phule G 0511-43-2 & 66.40 & 125.91 & 186.13 & 8.67 & 13.44 & 32.12 & 295.40 & 777.56 & 1122.79 \\
\hline 7 & Phule G 0752 & 74.31 & 132.19 & 182.78 & 8.02 & 13.74 & 29.29 & 345.16 & 1015.89 & 1264.63 \\
\hline 8 & ICC 4958 & 67.71 & 128.70 & 206.88 & 7.79 & 12.88 & 36.02 & 322.73 & 1015.51 & 1521.66 \\
\hline 9 & Vijay & 73.60 & 135.36 & 200.30 & 7.56 & 15.36 & 34.27 & 289.70 & 888.83 & 1253.48 \\
\hline \multirow[t]{8}{*}{10} & Digvijay & 70.00 & 142.65 & 226.03 & 6.24 & 14.66 & 33.44 & 250.39 & 743.02 & 1048.95 \\
\hline & Tolerant mean & 70.4 & 132.96 & 200.42 & 7.66 & 14.02 & 33.03 & 300.68 & 888.16 & 1242.30 \\
\hline & Mean & 69.87 & 125.10 & 184.62 & 7.31 & 12.10 & 27.58 & 259.47 & 640.89 & 917.61 \\
\hline & & & SE士 & CD at $5 \%$ & & $\mathrm{SE}_{ \pm}$ & $\begin{array}{l}\text { CD at } \\
5 \%\end{array}$ & & $\mathrm{SE}_{ \pm}$ & CD at $5 \%$ \\
\hline & \multicolumn{2}{|l|}{ Condition } & 0.39 & 1.11 & & 0.046 & 0.13 & & 2.06 & 5.82 \\
\hline & \multicolumn{2}{|l|}{ Genotype } & 0.23 & 0.68 & & 0.028 & 0.078 & & 1.25 & 3.54 \\
\hline & \multicolumn{2}{|c|}{ Condition X Genotype } & 1.24 & 3.52 & & 0.14 & 0.41 & & 6.51 & 18.40 \\
\hline & \multicolumn{2}{|c|}{ CV \% } & & 1.70 & & & 1.59 & & & 1.85 \\
\hline
\end{tabular}


In the present investigation, it was observed that a severe progressive stress in chickpea leads to about 3.35 fold more accumulation of proline as compare to control while 1.57 fold increase was observed in progressive mild stress.

The tolerant genotypes Digvijay, Vijay and ICC 4958 accumulated higher proline content under stress condition. The highest per cent increase of 78.7 and 281.5 was observed in tolerant genotype than 32.3 and 182.2 in susceptible genotypes under moderate and severe stress, respectively over unstressed control.

Patil (2010) observed that PEG stress increased mean proline content upto 7-folds in tolerant as compared to 3-folds in susceptible sorghum genotypes. Kumar et al., (2011) observed that a sever progressive stress in pigeon pea leads to about 25 fold more accumulation of proline as compared to control of same age group while 6 fold increase was observed in progressive mild stress.

\section{Glycine betaine}

The effect of PEG 6000 induced osmotic stress of $-0.4 \mathrm{MPa}$ and $-1.2 \mathrm{MPa}$ clearly demonstrated significant variation in glycine betaine accumulation among susceptible and tolerant genotypes. The mean per cent increase in the level of glycine betaine in the tolerant genotypes was 72.2 and 189.9 per cent as against 41.7 and 93.3 per cent in susceptible genotypes under moderate and severe stress, respectively. The susceptible genotypes showed the lowest accumulation in glycine betaine under stress condition probably because of reduction in relative leaf water content.

The tolerant genotype ICC 4958 accumulated significantly highest glycine betaine content of 25.16 and $12.65 \mu \mathrm{mol} \mathrm{g}{ }^{-1} \mathrm{fw}$ followed by Digvijay with 22.96 and $14.23 \mu \mathrm{mol} \mathrm{g}{ }^{-1} \mathrm{fw}$ under severe and moderate stress condition, respectively than all genotypes under study.

The results are in agreement with Khan et al., (2010) and Wu et al., (2014), who reported the significant increase in glycine betaine content in linseed and sorghum seedlings under $\mathrm{NaCl}$ stress compared to the control.

\section{Antioxidative enzymes}

\section{Super oxide dismutase}

Superoxide radicals are toxic byproducts of oxidative metabolism. Thus, the dismutation of superoxide radicals into $\mathrm{H}_{2} \mathrm{O}_{2}$ and $\mathrm{O}_{2}$ by SOD is necessary to protect the plant tissue from damage. It is found that SOD activity of tolerant genotypes was higher than the sensitive genotypes. The results (Table 4) revealed that SOD activity differs between susceptible and tolerant genotypes under PEG induced osmotic stress. The higher per cent increase in SOD activity of 88.8 and 184.7 per cent in tolerant genotypes than 69.1 and 143.6 per cent increase in susceptible genotype over unstressed control at $-0.4 \mathrm{MPa}$ and -1.2 $\mathrm{MPa}$, respectively. The present study shows that tolerant genotypes probably developed efficient antioxidative defense system than susceptible ones to dismutase active oxygen species generated to cope with oxidative stress under extremely adverse condition.

Kumar et al., (2011) reported that the activities of SOD and POD in pigeon pea enhances by increasing in both progressive stress induced by PEG as compare to control.

\section{Catalase}

The catalase activity of chickpea leaves was increased in both mild and severe stress 
condition as compare to control plant leaves. Catalase is tetrameric heme containing enzymes with the potential to directly dismutase $\mathrm{H}_{2} \mathrm{O}_{2}$ into $\mathrm{H}_{2} \mathrm{O}$ and $\mathrm{O}_{2}$ and is indispensible for $\mathrm{ROS}$ detoxification during stress condition. The higher per cent increase in CAT activity of 83 and 331.2 in tolerant genotypes and a minimum of 46.2 and 217.9 per cent in susceptible types over unstressed control under moderate and severe stress, respectively.

The higher activity observed in tolerant genotypes viz., ICC 4958, Vijay and Digvijay indicate their ability to scavenge harmful radicals under water stress conditions which could cause membrane damage. The significantly highest catalase activity of 36.02 $\mu$ mol $\mathrm{H}_{2} \mathrm{O}_{2}$ decomposed $\mathrm{mg}^{-1}$ protein $\min ^{-1}$ was found in ICC 4958 than genotypes under severe stress $(-1.2 \mathrm{MPa})$ condition while Vijay (15.36 $\mu \mathrm{mol} \mathrm{H}_{2} \mathrm{O}_{2}$ decomposed $\mathrm{mg}^{-1}$ protein $\mathrm{min}^{-1}$ ) showed significantly highest catalase activity under moderate stress (-0.4 Mpa). The increase in catalase activity was reported in several crops under $\mathrm{NaCl}$ stressed condition: in linseed by Khan et al., (2010), in cucumber by Du et al., (2010) and in chickpea by Rasool et al., (2013).

\section{Ascorbate peroxidase activity}

The results revealed that the stressed leaves of susceptible chickpea genotypes showed lower mean APX activity than tolerant genotypes. As regards the mean per cent increase over control, the susceptible types exhibited a much lower per cent increase of 80.3 and 171.6 while tolerant types with higher mean of 195.4 and 313.2 per cent under moderate and severe stress, respectively.

APX is involved in scavenging of $\mathrm{H}_{2} \mathrm{O}_{2}$ in water-water and ASH-GSH cycle and utilizes $\mathrm{ASH}$ as the electron donor. Significantly highest activity of 1521.66 and $1015.51 \mathrm{n}$ moles of ascorbate oxidized $\mathrm{mg}^{-1}$ protein min 1 was observed in a tolerant genotype ICC 4958 at severe and moderate stress, respectively. Raheleh et al., (2012) reported that the chickpea leaf APX activity in tolerant genotypes was higher than the susceptible genotypes under drought condition.

Thus, it indicates that plants have developed an antioxidant defense system to cope with oxidative damage under extremely adverse conditions that include $\mathrm{H}_{2} \mathrm{O}_{2}$ sensitive antioxidative enzyme APX.

In conclusion this investigation indicates that a progressive water stress induced by PEG 6000 causes significantly physiological and biochemical changes in chickpea. Stomatal conductance seems to be the main factor in photosynthesis and limited transpiration under drought conditions. RLWC parameter can be used to select high yielding genotypes that maintain cell turgour under water stress environment.

Progressive water deficit stress increased concentration of protein and glycine betaine. The accumulation of the osmolytes can help the chickpea plants to maintain the cell turgour and the structural integrity of membranes.

Result of this study showed that under increased stress condition, activity of antioxidative enzymes increased. The increased activities of antioxidant enzymes including SOD, CAT and APX indicates that an effective antioxidant defense mechanism process by chickpea for scavenging reactive oxygen species and protect them from destructive oxidative reaction. Therefore, considering the results obtained from yhe study, protein content, SOD and APX activity can be useful biochemical markers for identifying tolerant genotypes. Finaly, results of pot study showed that ICC 4958 cultivar is 
the most tolerant one among the studied cultivars.

However, the data presented (Tables 1-4) here reflects the importance of a physiological and biochemical analysis of plant responses, which must be acomplained with field experiments and further evaluation. Therefore, more investigations are required to ascertain this conclusion.

\section{References}

Aebi, H. 1984. Catalase in vitro. Meth. Enzymol., 105: 121-126.

Bates, L., Walden, R.P. and Teare, I.D. 1973. Rapid determination of free proline for water stress studies. Plant Soil, 38: 205-207.

Bayomi, T.Y., Eid, M., Metwali, E.M. 2008. Application of physiological and biochemical indices as a screening technique for drought tolerance in wheat genotypes. Afr. J. Biotech., 7: 2341-2352.

Bray, E.A., Bailey-Serres, J., Weretilnyk, E. 2000. Responses to abiotic stresses. In Biochemistry and Molecular Biology of Plants, eds. Buchanan BB, Gruissem W, Jones RL, Amer Soc Plant Physiol, Rockville, MD, 11581203

Costa-Franca, M. G., Thi, A. T.P., Pimentel, C., Rossiello, R.O.P., Zuily-Fodil, Y. and Laffray, D. 2000. Differences in growth and water relations among

Phaseolus vulgaris cultivars in response to induced drought stress. Environ. Expt. Bot., 43: 227-237.

Chaves, M.M., Pereira, J.S. and Marco, J.2003. Understanding plant response to drought-from gens to the whole plant. Functional Plant Biol., 30: 239264.

Dhindsa, R.A., Dhinda, P.P. and Thorpe, T.A. 1981. Senescence: correlated with increased permeability and lipid peroxidation and decreases levels of superoxide dismutase and catalase. $J$. Expt. Bot., 126: 93-101.

Du, C.X., Fan, H.F. and Guo, S.R. 2010. Applying spermidine for differential responses of antioxidant enzymes in cucumber subjected to short-term salinity. J. Am. Soc. Hort. Sci., 135(1): 18-24.

Grassi, G. and Magnani, F. 2005. Stomatal, mesophyll conductance and biochemical limitations to photosynthesis as affected by drought and leaf ontogeny in ash and oak trees. Plant, Cell and Environ., 28: 834-849.

Henderson, J.C. and Davies Jr., F.T. 1990. Drought acclimation and the morphology of mycorrhizal Rosa hybrids L. cv. 'Ferdy' independent of leaf elemental content. New Phytol., 175: 503-510.

Hirich, A., Omari, H.E., Jacobsen, S.E., Lamaddalena, N., Hamdy, A., Ragab, R., Jelloul, A. and Allah, R.C. 2014. Chickpea (Cicer arietinum L.) physiological, chemical and growth responses to irrigation with saline water. Aus. J. Crop Sci., 8(5): 646654.

Khan, M.N., Siddiqui, M.H., Mohammad, F., Naeem, M. and Khan, M.M.A. 2010. Calcium chloride and gibberellic acid protect linseed (Linum usitatissimum L.) from $\mathrm{NaCl}$ stress by inducing antioxidative defense system and osmoprotectant accumulation. Acta Physiol. Plant, 32: 121-132.

Kataria, N. and Singh, N. 2013. Amelioration of water stress by potassium fertilizer in chickpea (Cicer arietinum L.). $J$. Trop. Plant Physiol., 5: 22-32.

Kumar, P., Deshmakh, P.S., Sairam, R.K., Kushvaha, S.R. and Sing, P. 2006. Biochemical and phonological evaluation of chickpea genotypes differing in drought tolerance. Indian 


\section{J. Plant Physiol., 11: 166-171.}

Michel, B.E. and M.R., Kaufman. 1973. The osmotic potential of polyethylene glycol 6000, Plant Physiol., 51: 914916.

Naderikharaji, R., Pakniyat, $\mathrm{H}$ and Biabani, A.R. 2008. Effect of drought stress on photosynthetic rate of four Rapeseed (Brassica napus) cultivars. J. Appl. Sci., 8(23): 4460-4463.

Nakona, Y. and Asada, K. 1981. Hydrogen peroxide is scavenged by ascorbic specific peroxide in spinach chloroplast. Plant Cell Physiol., 22: 867-880.

Raheleh, R., Khavari-Nejad, R., Ali, G., Abdolreza, B., Farzaneh, N. and Masoud, R. 2012. Use of biochemical indices and antioxidant enzymes as a screening technique for drought tolerance in Chickpea genotypes (Cicer arietinum L.) Afr. J. Agric. Res., 7(39): 5372-5380.

Rasool, S., Ahmad, A. and Siddiqi, T.O. 2012. Differential response of chickpea genotypes under salt stress. J. Funct. Environ. Bot., 2(1): 59-64.

Sanchez-Mora N., Presmanes, M.C., Monroy V, Moreno N., Lara-Martinez, J.M., Aladro M.H., Alvarez-Fernandez E. 2008. Micropapillary lung adenocarcinoma: A distinctive histological subtype with prognostic significance. Case series. Hum. Pathol., 39: 324-330.
Savoure, A., Jaoua, S., Hua, X.J., Ardiles, W., Van Montagu, M. and Verbruggen, N. 1995. Isolation, characterization, and chromosomal location of a gene encoding the $\Delta^{1}$-pyrroline-5carboxylate synthetase in Arabidopsis thaliana. FEBS Lett., 372: 13-19.

Stumpf, D.K. 1984. Quantification and purification of quaternary ammonium compounds from halophyte tissue. Plant Physiol., 75: 273-274.

Wang, W.B., Kim, Y.H., Lee, H.S., Kim, K.Y., Deng, X.P. and Kwak, S.S. 2009. Analysis of antioxidant enzyme activity during germination of alfalfa under salt and drought stress. Plant Physiol. Biochem., 47: 570-577.

Wu, G., Zhou, Z., Chen, P., Tang, X., Shao, H. and Wang, H. 2014. Comparative ecophysiological study of salt stress for wild and cultivated soybean species from the yellow river delta, China. The Scient. World J., 10: 1-13.

Yucel, D.O., Anlarsal, A.E., Mart, D. and Yucel, C. 2010. Effects of drought stress on early seedling growth of Chickpea (Cicer arietinum L.) genotypes, World Appl. Sci. J., 11(4): 478-485.

Zgalli, H., Steppe K. and Lemeur R. 2005. Photosynthetic, Physiological and Biochemical Responses of Tomato Plants to Polyethylene Glycol induced water deficit. J. Integr. Plant. Biol., 47(12): 1470-1478.

\section{How to cite this article:}

Awari, V.R., U.S. Dalvi, P.K. Lokhande, V.Y. Pawar, S.N. Mate, R.M. Naik and Mhase, L.B. 2017. Physiological and Biochemical Basis for Moisture Stress Tolerance in Chickpea under Pot Study. Int.J.Curr.Microbiol.App.Sci. 6(5): 1247-1259. doi: https://doi.org/10.20546/ijcmas.2017.605.135 